\title{
Lessons from an ICU recovery clinic: two cases of meralgia paresthetica after prone positioning to treat COVID-19-associated ARDS and modification of unit practices
}

\author{
Amy L. Bellinghausen ${ }^{1 *}$ D, Jamie N. LaBuzetta ${ }^{2}$, Frank Chu ${ }^{3}$, Francesca Novelli ${ }^{4}$, Anthony R. Rodelo ${ }^{4}$ and
} Robert L. Owens ${ }^{1}$

Keywords: Meralgia paresthetica, Prone, COVID-19, Acute respiratory distress syndrome, ICU recovery clinic

\section{Main text}

Prone positioning is one of the few interventions in acute respiratory distress syndrome (ARDS) which has a proven mortality reduction [1]. Due to the coronavirus disease 2019 (COVID-19) pandemic, severe ARDS cases have sharply increased worldwide, increasing the need for proning. Some centers have also encouraged non-intubated patients with hypoxemia due to COVID-19 to self-prone [2]

Although generally considered low risk, pressure-related complications can occur during proning and differ from those that occur in supine patients. We present two cases of COVID-19-associated ARDS treated with prone positioning who developed meralgia paresthetica that was diagnosed in our ICU recovery clinic. Meralgia paresthetica (MP) results from compression injury of the lateral femoral cutaneous nerve between the anterior superior iliac spine and the inguinal ligament (Fig. 1); this mononeuropathy results in sensory abnormalities in the anterolateral thigh [3]. To our knowledge, there is only one other reported case of MP in prone positioning for ARDS, although it has been reported after surgical prone positioning in up to $24 \%$ of cases $[4,5]$.

The first patient was a 53-year-old man with diabetes (well-controlled, glycosylated hemoglobin 6.5 to $7.0 \%$ ), obesity (BMI 30.9), and hypertension, who was mechanically

\footnotetext{
* Correspondence: amyb@health.ucsd.edu

'Division of Pulmonary, Critical Care, Sleep Medicine and Physiology, University of California San Diego, San Diego, CA, USA

Full list of author information is available at the end of the article
}

ventilated for 11 days. He had a single session of proning for $16 \mathrm{~h}$. He was extubated and discharged home on day 19 of admission. During his ICU recovery clinic visit (2 months after discharge), he reported isolated left-sided, welldemarcated anterior thigh numbness, new since his hospital stay. He had no associated weakness or pain, though did also endorse some non-painful numbness and tingling in

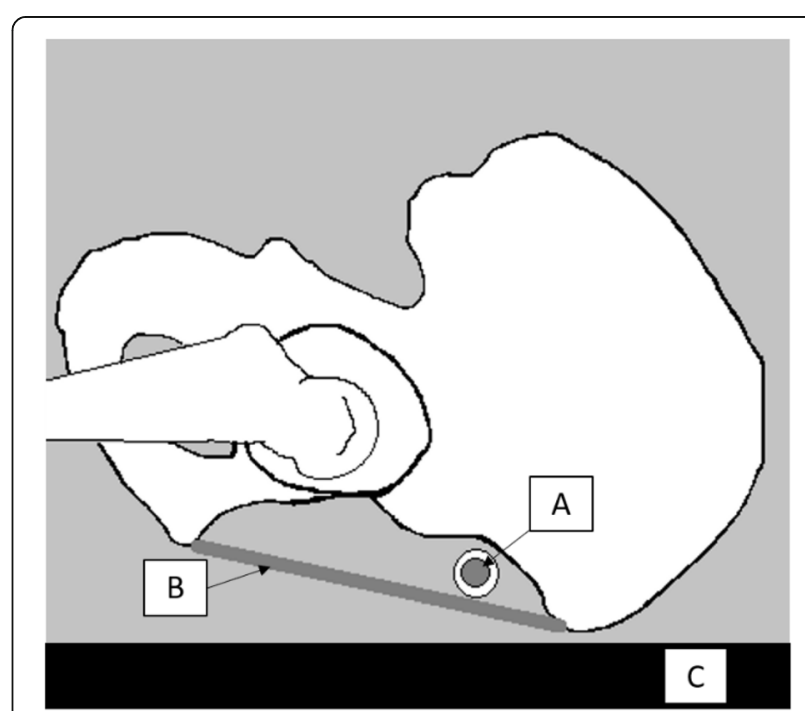

Fig. 1 Lateral femoral cutaneous nerve compression in the prone position. (A) Lateral femoral cutaneous nerve (cross-section). (B) Inguinal ligament. (C) Surface of the hospital bed

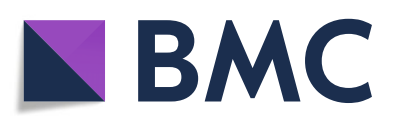

(C) The Author(s). 2020 Open Access This article is licensed under a Creative Commons Attribution 4.0 International License, which permits use, sharing, adaptation, distribution and reproduction in any medium or format, as long as you give appropriate credit to the original author(s) and the source, provide a link to the Creative Commons licence, and indicate if changes were made. The images or other third party material in this article are included in the article's Creative Commons licence, unless indicated otherwise in a credit line to the material. If material is not included in the article's Creative Commons licence and your intended use is not permitted by statutory regulation or exceeds the permitted use, you will need to obtain permission directly from the copyright holder. To view a copy of this licence, visit http://creativecommons.org/licenses/by/4.0/ The Creative Commons Public Domain Dedication waiver (http://creativecommons.org/publicdomain/zero/1.0/) applies to the data made available in this article, unless otherwise stated in a credit line to the data. 
the bilateral second and third toes, which was also new since discharge, without associated weakness, thought to be potentially due to peroneal nerve compression. As the symptoms were not troublesome to the patient, further electrophysiological testing was deferred.

The second patient was a 57-year-old man, without known past medical history who was intubated, mechanically ventilated, and proned for a total of $42 \mathrm{~h}$, over three sessions. He was extubated after 10 days and discharged home on day 24 of admission. At his ICU recovery clinic visit (7 weeks after discharge), he endorsed left anterior thigh numbness without associated weakness, which was bothersome though not painful. His primary care provider had prescribed capsaicin cream (which depletes substance $P$, reducing nerve sensitivity to painful stimuli), which had not improved the symptoms. The patient declined referral for electrophysiological examination.

After review of these cases, we altered our unit practice regarding padding of the anterior hips while patients are in the prone position. Previously, we placed 4-in. square, adhesive, foam absorbent dressings over each anterior superior iliac spine, and a pillow under the "up" hip (alternating sides every $2 \mathrm{~h}$ ). Subsequently, we have changed our practice to more evenly distribute pressure over the hip, with egg-crate style foam padding between the "down" hip and the bed (Fig. 2).

We present these cases not only to highlight an uncommonly recognized but potentially preventable complication of prone positioning in the ICU, but to show how data gathered in an ICU recovery clinic, staffed by intensivists, can be "fed back" into the ICU where patients were treated, and improve the quality of care that patients receive [6]. "Identifying otherwise unseen targets for ICU quality improvement" has been postulated as one way that ICU recovery clinics might improve care, yet there are few published examples. If these patients returned to their primary care physicians, it is less likely that the cause of the MP would be known, nor would practice change. Lessons like these show the potential value of ICU recovery clinics, not only in treating post-intensive care syndrome, but in changing its underlying causes.

(a)

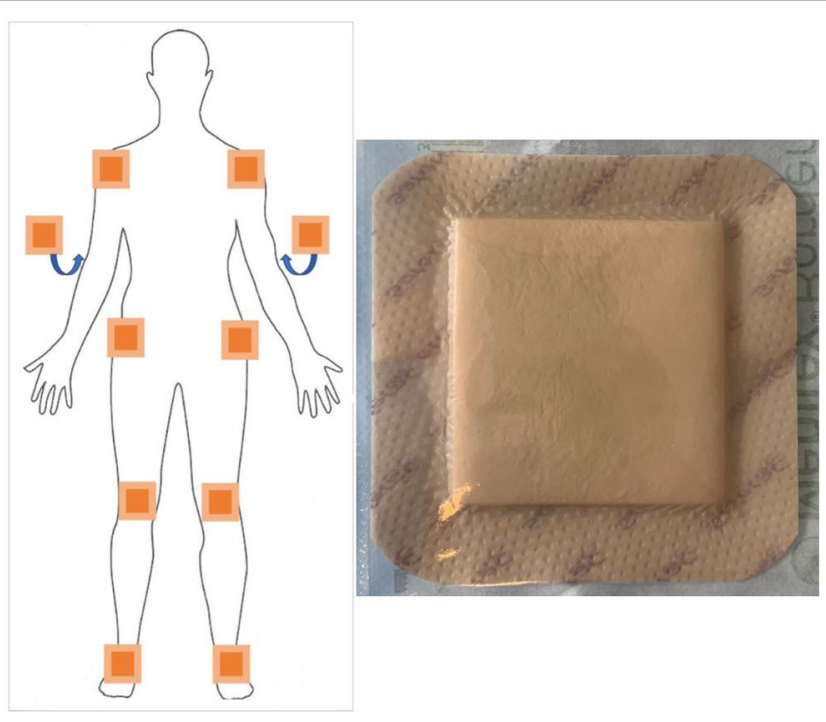

(b)

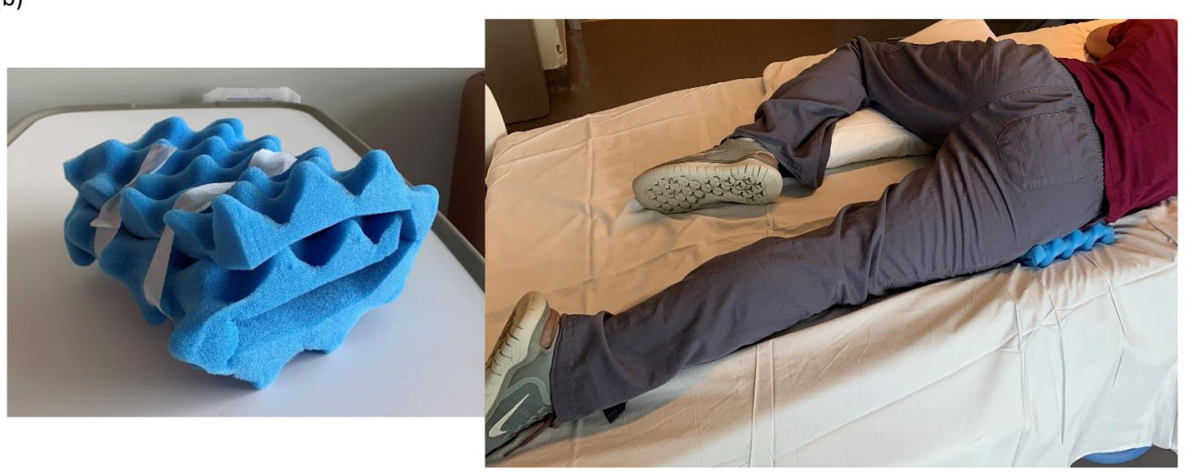

Fig. 2 a Absorbent, adhesive, foam dressings $(10 \mathrm{~cm} \times 10 \mathrm{~cm})$ and locations used for the initial pressure offloading technique. b Addition of eggcrate foam under the "down hip" in revised pressure offloading technique 


\title{
Abbreviations
}

COVID-19: Coronavirus disease 2019; ARDS: Acute respiratory distress syndrome; ICU: Intensive care unit; MP: Meralgia paresthetica

\section{Acknowledgements}

Thank you to Kelsey Desmond, RN, CCRN, for the assistance with the figures and implementing the change in practice.

\section{Authors' contributions}

$A B$ identified the two cases described and was a major contributor in writing the manuscript. FC and RO assisted in the manuscript revision and participated in the ICU recovery clinic visits for these patients. All authors read and approved the final manuscript.

\section{Funding}

There was no specific funding for this study; research time for author $A B$ is funded by the NHLBI T32 Institutional Training Award (HL134632).

\section{Availability of data and materials}

\author{
Not applicable
}

\section{Ethics approval and consent to participate}

Not applicable

\section{Consent for publication}

Not applicable, no identifiable patient information included

\section{Competing interests}

The authors declare that they have no competing interests.

\section{Author details}

'Division of Pulmonary, Critical Care, Sleep Medicine and Physiology, University of California San Diego, San Diego, CA, USA. ${ }^{2}$ Department of Neurosciences, Division of Neurocritical Care, University of California San Diego, San Diego, CA, USA. ${ }^{3}$ Department of Pharmacy, University of

California San Diego, San Diego, CA, USA. ${ }^{4}$ Critical Care Nursing, University of California San Diego, San Diego, CA, USA.

Received: 30 July 2020 Accepted: 14 September 2020

Published online: 27 September 2020

\section{References}

1. Guérin C, Reignier J, Richard J-C, Beuret P, Gacouin A, Boulain T, et al. Prone positioning in severe acute respiratory distress syndrome. N Engl J Med. 2013;368(23):2159-68 Available from: http://www.nejm.org/doi/10.1056/ NEJMoa1214103. [cited $2020 \mathrm{Jul} 7$ 7].

2. Elharrar $X$, Trigui $Y$, Dols AM, Touchon F, Martinez S, Prud'Homme E, et al. Use of prone positioning in nonintubated patients with COVID-19 and hypoxemic acute respiratory failure. JAMA. 2020;323:2336-8 Available from: https://www. [cited 2020 Jul 8].

3. Cheatham SW, Kolber MJ, Salamh PA. Meralgia paresthetica: a review of the literature. Int J Sports Phys Ther. 2013;8(6):883-93 Available from: http:// www.ncbi.nlm.nih.gov/pubmed/24377074 [cited 2020 Jul 8].

4. Juhl CS, Ballegaard M, Bestle MH, Tfelt-Hansen P. Case report meralgia paresthetica after prone positioning ventilation in the intensive care unit. 2016, Available from: https:/doi.org/10.1155/2016/7263201. [cited 2020 Jul 7].

5. Cho KT, Lee HJ. Prone position-related meralgia paresthetica after lumbar spinal surgery: a case report and review of the literature. J Korean Neurosurg Soc. 2008;44(6):392-5 Available from:/pmc/articles/PMC2615145/ ?report=abstract [cited $2020 \mathrm{Jul} 8$ ].

6. Haines KJ, Sevin CM, Hibbert E, Boehm LM, Aparanji K, Bakhru RN, et al. Key mechanisms by which post-ICU activities can improve in-ICU care: results of the international THRIVE collaboratives. Intensive Care Med. 2019:45(7):939-47 Available from: https://doi.org/10.1007/s00134-019-05647-5 [cited $2020 \mathrm{Jul} 9$ ].

\section{Publisher's Note}

Springer Nature remains neutral with regard to jurisdictional claims in published maps and institutional affiliations.

Ready to submit your research? Choose BMC and benefit from:

- fast, convenient online submission

- thorough peer review by experienced researchers in your field

- rapid publication on acceptance

- support for research data, including large and complex data types

- gold Open Access which fosters wider collaboration and increased citations

- maximum visibility for your research: over $100 \mathrm{M}$ website views per year

At BMC, research is always in progress.

Learn more biomedcentral.com/submissions 